\title{
Mathematical Modeling of Operation Process of Dynamic Membrane Bioreactor
}

\author{
Ji-Zhi Lin ${ }^{1}$, Qian Zhang2 ${ }^{2}$ Jun-Ming Hong2* \\ 1 Department of Science and Technology Research, Huaqiao University, Xiamen, Fujian, China. \\ 2 College of Chemical Engineering, Huaqiao University, Xiamen, Fujian, China. \\ * Corresponding author. Tel.: 18905920966; email: jmhong@hqu.edu.cn \\ Manuscript submitted March 15, 2016; accepted July 10, 2016. \\ doi: 10.17706/ijbbb.2016.6.3.84-91
}

\begin{abstract}
The effects of different influent $\mathrm{C} / \mathrm{N}$ ratios on the removal efficiencies of COD, total nitrogen, ammonia, nitrite and nitrate were investigated in a dynamic membrane bioreactor (DMBR), which was used to treat synthetic domestic wastewater. A simplified activated sludge model(SASM) was proposed, which based on the activated sludge model No.1(ASM1). The results showed the effluent concentrations of COD were less than $50 \mathrm{mg} \cdot \mathrm{L}^{-1}$ in the DMBR. The removal efficiencies of COD were more than $85 \%$ in the different $\mathrm{C} / \mathrm{N}$ ratios. The effluent concentrations of total nitrogen and ammonia were gradually increased as the ratios of $\mathrm{C} / \mathrm{N}$ decreased. When the ratio of $\mathrm{C} / \mathrm{N}$ was more than 6.75 , the removal efficiencies of total nitrogen and ammonia were more than $50 \%$ and $60 \%$, respectively. The SASM was feasible for DMBR simulation and the simulated values of nitrite and nitrate almost equal to the experiment values.
\end{abstract}

Key words: Dynamic membrane bioreactor (DMBR), simplified of activated sludge model (SASM), C/N ratio.

\section{Introduction}

Membrane bioreactor (MBR) with a microfiltration (MF) or an ultrafiltration (UF) membrane with a bioreactor has got great attention on wastewater treatment and reclamation for years [1]. Many merits, including good effluent quality, higher mixed liquor suspended solids, reduced system volume, and perfect sludge retention time control, can be achieved by using membranes in bioreactor [2], [3]. MBR has been considered as one of the most promising processes for wastewater treatment. However, the high costs and the inevitable membrane fouling of the membrane module limit its application [4].

The dynamic membrane is also called secondary membrane or formed-in-place membrane [5]. It is formed by filtering one or more specific colloidal components or the substances in the solution. The dynamic membrane process is one of the methods to solve the problems of membrane fouling. For dynamic membrane preparation, the cheaper filter media such as mesh, non-woven fabric and filter-cloth are used as supporter [6]-[8]. Dynamic membrane could be formed and re-formed in-situ on the supporter. Once the membrane is severely fouled, the dynamic layer can be easily replaced by a new deposited layer to decrease the cost. It is the hot topic to continuously remove the organics and nitrogen in a single reactor [9]. The ratio of $\mathrm{C} / \mathrm{N}$, as the main factor for ammonia degradation, can also effectively influence the wastewater treatment efficiency, especially for decreasing the effluent concentration of ammonia [10]-[13].

Models that can accurately describe the MBR process are valuable on the design, prediction, and control of MBR systems. Complex models that are practical for real applications can greatly assist in capitalizing on 
the benefits of MBR technology. Activated sludge model no. 1(ASM1) was developed to model biological treatment for organic carbon removal, nitrification, and denitrification. The model can be used to predict oxygen demand and sludge production in an activated sludge system. The numbers of stoichiometric parameters, kinetic parameters, components and reaction process were five, fourteen, thirteen, eight, respectively, in the ASM1. A matrix format is used to identify the rate processes that affect the fate of each component [14].

The ASM1 was reported to be applied to an aerobic MBR process for actual municipal wastewater treatment [15]. The results from the simulations provided a better understanding of the mechanisms and kinetics of the MBR process including sludge removal [16].

In this study, a polyester filtration cloth with the size of $37 \mu \mathrm{m}$ was used to replace the conventional MF or UF membranes to build a DMBR for wastewater treatment. The effluent concentrations of COD, TN, $\mathrm{NH}_{4}^{+}-\mathrm{N}$, $\mathrm{NO}_{2}-\mathrm{N}$ and $\mathrm{NO}_{3}^{--\mathrm{N}}$ were investigated by treating synthetic wastewater with different $\mathrm{C} / \mathrm{N}$ ratios in the DMBR. At the same time, a simplified activated sludge model (SASM) was to simulate the DMBR, which based on the ASM1 model.

\section{Materials and Methods}

\subsection{Wastewater and Seeds}

The components of synthetic wastewater were $278 \mathrm{mg} \cdot \mathrm{L}^{-1}$ glucose, $278 \mathrm{mg} \cdot \mathrm{L}^{-1} \mathrm{starch}, 13.16 \mathrm{mg} \cdot \mathrm{L}^{-1}$ potassium dehydrogenase phosphate, $28.65 \sim 332.00 \mathrm{mg} \cdot \mathrm{L}^{-1}$ ammonium sulphate, $66.0 \mathrm{mg} \cdot \mathrm{L}^{-1}$ magnesium sulphate, $111.0 \mathrm{mg} \cdot \mathrm{L}^{-1}$ sodium bicarbonate, $6.0 \mathrm{mg} \cdot \mathrm{L}^{-1}$ manganese sulphate, $6.0 \mathrm{mg} \cdot \mathrm{L}^{-1}$ calcium chloride, 2.0 $\mathrm{mg} \cdot \mathrm{L}^{-1}$ ferrous sulphate [17]. The influent concentrations of COD, total nitrogen, ammonia and total phosphorus were 237.6 311.4 mg. $\mathrm{L}^{-1}, \quad 8.00 \sim 70.00 \mathrm{mg} \cdot \mathrm{L}^{-1}, \quad 7.50 \sim 70.00 \mathrm{mg} \cdot \mathrm{L}^{-1}, \quad 2.37 \sim 3.28 \mathrm{mg} \cdot \mathrm{L}^{-1}$, respectively. The $\mathrm{pH}$ of influent solution was $6.5 \sim 7.5$.

The biomass was inoculated from an oxidation ditch in a municipal wastewater treatment plant. The activity sludge was acclimated by a fill-and-draw process for one month with a synthetic wastewater.

\subsection{Experiment and Operation}

Fig. 1 showed the schematic diagram of the DMBR process. The synthetic wastewater was flowed into a bucket and was fed into the bioreactor by a peristaltic pump. The effective volume of the DMBR was about 12.5 L. There were two membrane modules, which were made of polyvinyl chloride and filtration cloth. Submerged flat-sheet membrane of polyester filtration cloth with the pore size of $37 \mu \mathrm{m}$ and the effective filtration area of $0.12 \mathrm{~m}^{2}$ was used in this study. A coarse bubble diffused aeration system was used to supply oxygen for biological reactions and to scour the membrane surface. Dissolved oxygen (D0) was $3.0 \sim 4.0 \mathrm{mg} \cdot \mathrm{L}^{-1}$, hydraulic retention time (HRT) was $2.78 \mathrm{~h}$. The operation cost was less than the classical MBR, because the effluent was driven by gravity. The experiment was conducted at constant flux. The membrane module was taken out and washed with water to recover the membrane flux for the next run once the head loss was more than $5 \mathrm{~cm}$.

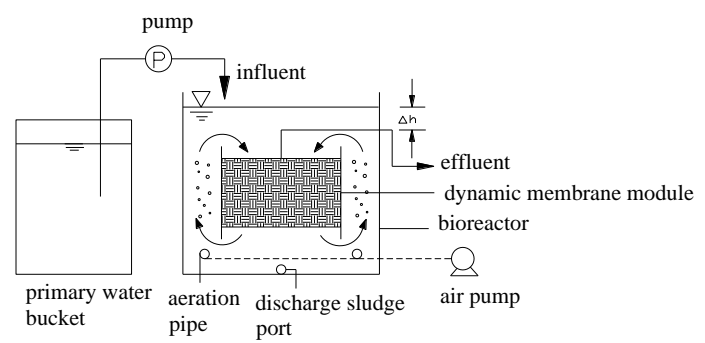

Fig. 1. Schematic diagram of the experimental setup. 


\subsection{Analytical Methods}

The influent and effluent qualities were simultaneously sampled every day. $\mathrm{pH}$, the influent and effluent concentrations of COD, TN, $\mathrm{NH}_{4}^{+}-\mathrm{N}, \mathrm{NO}_{2}^{--}-\mathrm{N}$ and $\mathrm{NO}_{3}^{-}-\mathrm{N}$ were measured by Chinese NEPA Standard Methods [18]. The modelling and simulating software Biowin (Environ Sim ASSOCIATES LTD, Canada) was used to perform model simulation and parameter estimation.

\section{Development of a Mathematical Model}

Since the limitation of parameters, the traditional ASM1 mode was difficult to use. A simplified activated sludge model (SASM) is proposed.

\subsection{Assumptions for Model}

There are three assumptions in the SASM.

1) There were three processes, carbon oxidation process, nitrification process and denitrification process in the SASM model, which was same to the ASM1.

2) Ammonification of soluble organic nitrogen was considered into the process of aerobic growth of heterotrophs in the SASM model. On one hand, the ammonisation process was too quick to play role in the prediction of the model [19]. On the other hand, when the heterotrophic microorganism hydrolysed soluble organic matter containing nitrogen, the ammonisation occurred, the reaction rate of ammonisation was the proportion of the removal rate of soluble substance.

3) The hydrolysis of entrapped organics and entrapped organic nitrogen were not considered due to the high oxygen concentration. The reason was that the concentration of dissolved oxygen was $3.0 \sim 4.0 \mathrm{mg} \cdot \mathrm{L}^{-1}$, which was considered the main electron acceptor in the submerged DMBR. In addition, sludge concentration of the DMBR was more than the classical activity sludge method. The entrapped biomass was less than the concentration of activated sludge. Thus, two components of particulate biodegradable organic nitrogen and soluble biodegradable organic nitrogen were cancelled.

\subsection{The Structure of SASM}

There were ten components and five processes in the SASM. The relation of components and processes was listed in the table 1 , which consisted of stoichiometric parameters and process rate models. From the table 1 , the number of stoichiometric parameters, kinetic parameters, components and reaction process were four, eight, ten, five, respectively, in the SASM. The number of parameters was less than ASM1. It suggested the model parameters of calculation and determination were reduced.

Eight material balance equations of state variables in the DMBR were list in the table 2. The model equations were mainly based on mass balances of the different model components. Biowin was used to calculate the differential equations.

Table 1. The Arrangement of Channels

\begin{tabular}{|c|c|c|c|c|c|c|c|c|c|c|c|c|}
\hline \multirow{3}{*}{$\mathrm{j}$} & \multirow{3}{*}{ Process } & \multicolumn{10}{|c|}{ Component i } & \multirow{3}{*}{$\begin{array}{l}\text { Process rate } \\
\rho_{\mathrm{j}}\left[\mathrm{M} /\left(\mathrm{L}^{3} \cdot \mathrm{L}\right]\right.\end{array}$} \\
\hline & & 1 & 2 & 3 & 4 & 5 & 6 & 7 & 8 & 9 & 10 & \\
\hline & & $\mathrm{SI}_{\mathrm{I}}$ & Ss & $\mathrm{X}_{\mathrm{I}}$ & $\mathrm{Xs}_{\mathrm{s}}$ & $\mathrm{X}_{\mathrm{B}, \mathrm{H}}$ & $\mathrm{X}_{\mathrm{B}, \mathrm{A}}$ & $\mathrm{X}_{\mathrm{P}}$ & So & $\mathrm{S}_{\mathrm{NO}}$ & $\mathrm{S}_{\mathrm{NH}}$ & \\
\hline 1 & $\begin{array}{l}\text { Aerobic growth of } \\
\text { heterotrophs }\end{array}$ & & $-\frac{1}{Y_{H}}$ & & & 1 & & & $-\frac{1-Y_{H}}{Y_{H}}$ & & $-i_{X B}$ & $\mu_{H}\left(\frac{S_{S}}{K_{S}+S_{S}}\right)\left(\frac{S_{O}}{K_{O, H}+S_{O}}\right) X_{B, H}$ \\
\hline 2 & Anoxic growth of heterotrophs & & $-\frac{1}{Y_{H}}$ & & & 1 & & & $-\frac{4.57-Y_{A}}{Y_{A}}$ & $-\frac{1-Y_{H}}{2.86 Y_{H}}$ & $-i_{x B}$ & $\mu_{H}\left(\frac{S_{S}}{K_{S}+S_{S}}\right)\left(\frac{K_{O . H}}{K_{O . H}+S_{O}}\right)\left(\frac{S_{N o}}{K_{N o}+S_{N O}}\right) \eta_{g} X_{B, H}$ \\
\hline 3 & Aerobic growth of autotrophs & & & & & & 1 & & & ${\frac{1}{Y_{A}}}^{H}$ & $-i_{x x}-\frac{1}{Y_{A}}$ & $\mu_{A}\left(\frac{S_{N H}}{K_{N H}+S_{N H}}\right)\left(\frac{S_{O}}{K_{O, A}+S_{O}}\right) X_{B, A}$ \\
\hline 4 & Aerobic decay of heterotrophs & & & & $1-f_{p}$ & -1 & & $f_{P}$ & & & & $b_{H} X_{B, H}$ \\
\hline 5 & Anoxic decay of autotrophs & & & & $1-f_{p}$ & & -1 & $f_{P}$ & & & & $b_{A} X_{B, A}$ \\
\hline
\end{tabular}




\subsection{Building of Simulation Process}

Activated sludge was involved in the three types of reactions in the DMBR. The main reactions were organics oxidation, ammonia oxidation and nitrate reduction. Membrane module mainly participated in the filtration. The membrane module had a good function of solid-liquid separation, the effluent turbidity was less than 1NTU, the concentration of suspend solid was under $5 \mathrm{mg} \cdot \mathrm{L}^{-1}$. The SASM was calculated by Biowin software, which was used to simulate the process of the DMBR.

\subsection{Model Calibration}

The mathematical model was including eight differential equations, which had been transferred into a computational code by Biowin software. The computational time was reduced and it was more modifiable.

Table 2. Mass Balance of Equations

\begin{tabular}{|c|c|c|}
\hline Component & Equations & \\
\hline $\mathrm{S}_{\mathrm{S}}$ & $V \frac{d S_{S}}{d t}=Q_{i n} S_{S}^{\text {in }}-Q_{\text {out }} S_{S}^{\text {out }}-\frac{1}{Y_{H}} \rho_{1} V-\frac{1}{Y_{H}} \rho_{2} V$ & (1) \\
\hline Xs & $V \frac{d X_{S}}{d t}=Q_{\text {in }} X_{S}^{\text {in }}-Q_{\text {out }} X_{S}^{\text {out }}+\left(1-f_{P}\right)\left(\rho_{4}+\rho_{5}\right) V$ & (2) \\
\hline $\mathrm{X}_{\mathrm{B}, \mathrm{H}}$ & $V \frac{d X_{B, H}}{d t}=Q_{i n} X_{B, H}^{\text {in }}-Q_{o u t} X_{B, H}^{\text {out }}+\left(\rho_{1}+\rho_{2}-\rho_{4}\right) V$ & (3) \\
\hline $\mathrm{X}_{\mathrm{B}, \mathrm{A}}$ & $V \frac{d X_{B, A}}{d t}=Q_{i n} X_{B, A}^{\text {in }}-Q_{\text {out }} X_{B, A}{ }^{\text {out }}+\left(\rho_{3}-\rho_{5}\right) V$ & (4) \\
\hline $\mathrm{S}_{\mathrm{NO}}$ & $V \frac{d S_{N O}}{d t}=Q_{i n} S_{N O}^{\text {in }}-Q_{o u t} S_{N O}{ }^{\text {out }}-\frac{1-Y_{H}}{2.86 Y_{H}} \rho_{2} V+\frac{1}{Y_{A}} \rho_{3} V$ & (5) \\
\hline $\mathrm{S}_{\mathrm{NH}}$ & $V \frac{d S_{N H}}{d t}=Q_{i n} S_{N H}^{\text {in }}-Q_{o u t} S_{N H}^{\text {out }}-i_{X B}\left(\rho_{1}+\rho_{2}\right) V+\left(-i_{X B}-\frac{1}{Y_{A}}\right) \rho_{3} V$ & (6) \\
\hline $\mathrm{X}_{\mathrm{I}}$ & $V \frac{d X_{I}}{d t}=Q_{\text {in }} X_{I}^{\text {in }}-Q_{\text {out }} X_{I}^{\text {out }}$ & (7) \\
\hline $\mathrm{S}_{\mathrm{I}}$ & $V \frac{d S_{I}}{d t}=Q_{i n} S_{I}^{\text {in }}-Q_{o u t} S_{I}^{\text {out }}$ & (8) \\
\hline
\end{tabular}

The model calibration had been carried out by considering different steps. Firstly, the model was calibrated by a try and error procedure, adjusting manually the model parameters to find the best fit between experiment and simulated values. Model outputted COD, TN, $\mathrm{NH}^{4+}-\mathrm{N}, \mathrm{NO}_{2}-\mathrm{N}$ and $\mathrm{NO}^{3-} \mathrm{N}$ at the effluent. Furthermore, the calibration was proceeded by two following procedures: when the error was increased, the components of influent were changed, if it didn't work, the kinetic parameters were changed. Following the try and error step, an automatic calibration was carried out. Adjusted model parameters were used to simulate the DMBR process and the values were list in the Table 3.

Table 3. The Value of Model Parameters

\begin{tabular}{cccc}
\hline \hline Parameter & Value & Parameter & Value \\
\hline $\mathrm{f}_{\mathrm{P}}$ & 0.08 & $\mu_{\mathrm{A}}$ & 0.8 \\
$\mathrm{i}_{\mathrm{XB}}$ & 0.086 & $\mathrm{~K}_{\mathrm{NH}}$ & 1.0 \\
$\mathrm{Y}_{\mathrm{A}}$ & 0.24 & $\mathrm{~K}_{\mathrm{O}, \mathrm{A}}$ & 0.4 \\
$\mathrm{~b}_{\mathrm{A}}$ & 1.0 & $\mu_{\mathrm{H}}$ & 8.0 \\
$\mathrm{k}_{\mathrm{h}}$ & 3.0 & $\mathrm{~b}_{\mathrm{H}}$ & 0.62 \\
\hline \hline
\end{tabular}

\section{Experiment and Modeling Results}

In this study, DO, HRT and the influent flow was $3.0 \sim 4.0 \mathrm{mg} \cdot \mathrm{L}^{-1}, 2.78 \mathrm{~h}$ and $4.5 \mathrm{~L} \cdot \mathrm{h}^{-1}$, respectively. The influent concentration of COD was $300 \mathrm{mg} \cdot \mathrm{L}^{-1}$. The effluent concentrations of COD, TN, $\mathrm{NH}_{4}{ }^{-}-\mathrm{N} \mathrm{NO}_{2}-\mathrm{N}$ and $\mathrm{NO}_{3}-\mathrm{N}$ were investigated by changing the influent concentration of ammonia. The process of the DMBR was 
simulated by the SASM.

\subsection{Effect of Influent $\mathrm{C} / \mathrm{N}$ Ratio on COD}

The effluent COD concentrations of experiment and simulated values were shown in Fig. 2. The DMBR had a good removal efficiency of COD in different $\mathrm{C} / \mathrm{N}$ ratios. The effluent concentrations of COD were less than $50 \mathrm{mg} \cdot \mathrm{L}^{-1}$, the removal efficiencies of COD were more than $85 \%$ in different $\mathrm{C} / \mathrm{N}$ ratios, when the influent concentration of ammonia was changed from $7.5 \mathrm{mg} \cdot \mathrm{L}^{-1}$ to $70.0 \mathrm{mg} \cdot \mathrm{L}^{-1}$. It suggested the influent concentration of ammonia had little effect on the removal efficiency of COD in the processing system.

Using the SASM, the simulated value was approximate to the experiment value. COD was divided to four components, which were soluble biodegradable substrate $\left(\mathrm{S}_{S}\right)$, particulate biodegradable organic matter $\left(X_{S}\right)$, particulate inert organic matter $\left(X_{I}\right)$ and soluble inert organic matter $\left(S_{I}\right)$ in the SASM. The concentration of $X_{I}$ and $S_{I}$ was stable during the experiment, because $X_{I}$ and $S_{I}$ were biodegradable organics. According to the equations of (7) and (8), the reaction rate of $X_{I}$ and $S_{I}$ were zero, when the flow of influent and effluent was unchanged. According to the equations of (1) and (2), the degradation rate of $S_{S}$ and $X_{S}$ was related to itself concentration and the amount of heterotrophic bacteria. Furthermore, $\mathrm{X}_{\mathrm{S}}$ was also related to the concentration of nitrite and nitrate, when the parameters of kinetic, stoichiometry and operation were unchanged. The effluent concentration of COD was considered as soluble organics, because the module had a good function of solid-liquid separation. Thus, the simulated value was consistent with the experiment value.

\subsection{Effect of Influent $\mathrm{C} / \mathrm{N}$ Ratio on Ammonia}

The effluent ammonia concentrations of experiment and simulated values were shown in Fig. 2. The effluent concentration of ammonia decreased, and the removal efficiency of ammonia increased, when the ratio of $\mathrm{C} / \mathrm{N}$ increased. The removal efficiency of ammonia was more than $60 \%$, when the ratio of $\mathrm{C} / \mathrm{N}$ was more than 6.75. The volumetric load of ammonia was achieved the maximum of $23.82 \mathrm{kgNH}_{4}{ }^{+}\left(\mathrm{m}^{3} \mathrm{~d}\right)^{-1}$, it was not related to the influent concentration of ammonia, when the ratio of $\mathrm{C} / \mathrm{N}$ was more than 6.75 . However, the SASM cannot used to simulate the DMBR when the ammonia load increases, unless the adjustment of operation parameters, such as HRT, DO and so on.

The simulated value was approximate to the experiment value, when the ratio of $\mathrm{C} / \mathrm{N}$ was more than 5.04 . According to the equation of (6), the degradation rate slowly increased, when the influent concentration of ammonia was quickly increased, which led to increase the effluent concentration of ammonia. The simulated value was less than the experiment value, when the ratio of $\mathrm{C} / \mathrm{N}$ was 4.29 . The ASM1 was suit for simulating the conventional activated sludge process, it did not consider the toxicity of microorganism in the high concentration of ammonia [20]. The influent concentration of ammonia was $70.00 \mathrm{mg} \cdot \mathrm{L}^{-1}$, the ratio of $\mathrm{C} / \mathrm{N}$ was less than 4.29, the series of ASM model was not suitable. It led to a big error between the simulated value and experiment value. Therefore, the SASM is more suitable for the influents simulation with $\mathrm{C} / \mathrm{N}$ greater than 5 .

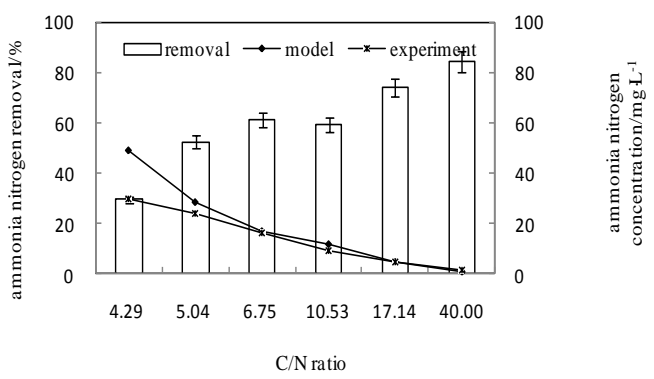

Fig. 2. Modeling and measuring the effluent ammonia concentration under different $\mathrm{C} / \mathrm{N}$ ratios. 


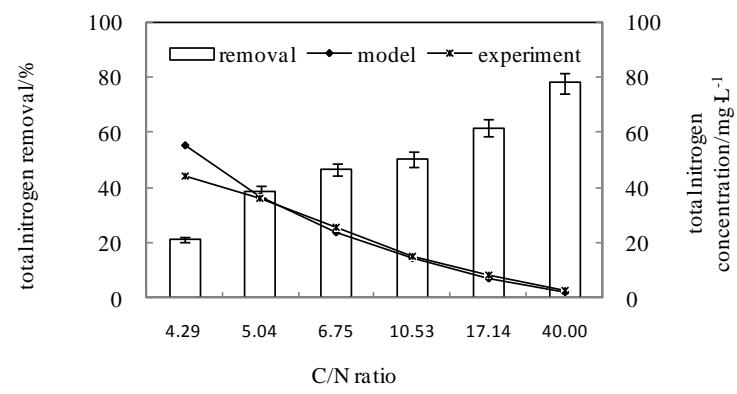

Fig. 3. Modeling and measuring the effluent total nitrogen concentration under different $\mathrm{C} / \mathrm{N}$ ratios.

\subsection{Effect of Influent $\mathrm{C} / \mathrm{N}$ Ratio on Total Nitrogen}

The effluent total nitrogen of experiment and simulated values were shown in Fig. 3. The effluent concentration of total nitrogen decreased, when the ratio of $\mathrm{C} / \mathrm{N}$ increased. The removal efficiency of total nitrogen was more than $50 \%$, when the ratio of $\mathrm{C} / \mathrm{N}$ was more than 6.75 . The simulated value was approximate to the experiment value, when the ratio of $\mathrm{C} / \mathrm{N}$ was more than 5.04.

Fig. 4 showed that the effluent concentration of nitrite and nitrate was less than $0.25 \mathrm{mg} \cdot \mathrm{L}^{-1}$ and 0.70 $\mathrm{mg} \cdot \mathrm{L}^{-1}$ in different $\mathrm{C} / \mathrm{N}$ ratios, respectively. From Fig. 5 , the simulated value of nitrite and nitrate was about to zero, due to the reaction rate of denitrification was quick and thorough in the DMBR process.

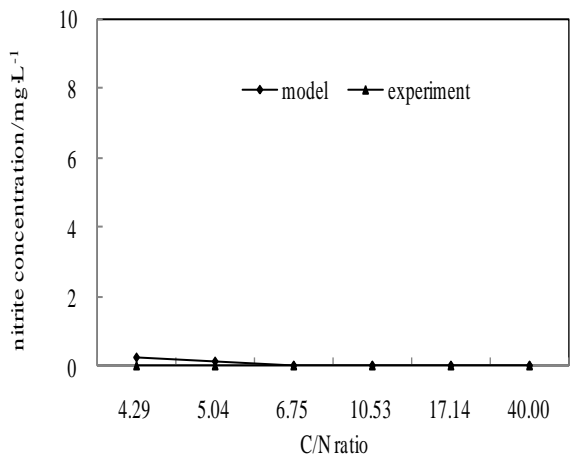

(a) nitrite

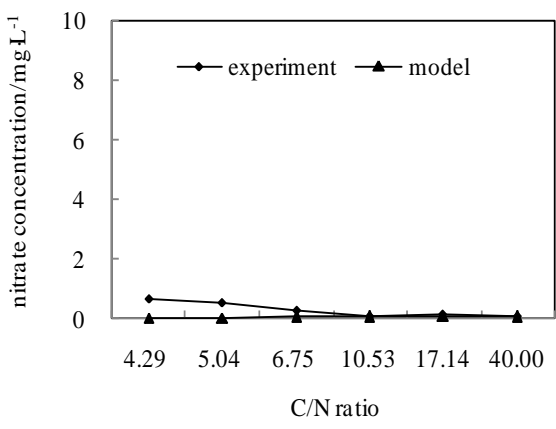

(b) nitrate

Fig. 4. Modeling and measuring the effluent nitrite and nitrate concentration under different $\mathrm{C} / \mathrm{N}$ ratios.

\section{Conclusion}

The dynamic membrane bioreactor (DMBR) process had been developed for wastewater treatment. The effluent concentrations of COD were under $50 \mathrm{mg} \mathrm{L}^{-1}$. The removal efficiency of ammonia and total nitrogen was more than $60 \%$ and $50 \%$, respectively. The SASM had been bullied in this paper. The number of the model components, reactor processes and parameters of the SASM was less than the ASM1. By using the SASM to simulate the DMBR, all the simulated values of TN, $\mathrm{NH}_{4}^{+}-\mathrm{N}, \mathrm{NO}_{2}^{--} \mathrm{N}$ and $\mathrm{NO}_{3}^{--} \mathrm{N}$ were approximate to the experiment values.

\section{Acknowledgment}

The authors gratefully acknowledge the financial support from Fujian province Science and Technology project Foundation 2014Y4006, Xiamen Technology project Foundation (3502Z20140057).

\section{References}

[1] Fan, B., \& Huang, X. (2002). Characteristics of a self-forming dynamic membrane coupled with a 
bioreactor for municipal wastewater treatment. Environment Science \& Technology, 36, 5245-5251.

[2] Marrot, B., Barrios-Martinez, A., Moulin, P., \& Roche, N. (2004). Industrial wastewater treatment in a membrane bioreactor: A review. Environment Progress, 23, 59-68.

[3] Ben, A. R. M., \& Semmers, M. J. (2002) Membrane bioreactor for wastewater treatment and reuse: A success story. Water Science \& Technology, 47(1), 1-5.

[4] Mutamim, N. S. A., Noor, Z. Z., \& Hassan, M. A. A., et al. (2013). Membrane bioreactor: Applications and limitations in treating high strength industrial wastewater. Chemical engineering journal, 225, 109-119.

[5] Kuberkar, V. T., \& Davis, R. H. (2000). Modeling of fouling reduction by secondary membranes. Journal of Membrane Science, 168, 158-243.

[6] Kiso, Y., Jung, Y. J., Ichinari, T., Park, M., \& Kitao, T. (2000). Nishimura K., Min K., Wastewater treatment performance of a filtration bioreactor equipped with a mesh as a filter material. Water Research, 34, 4143-4150.

[7] Ersahin, M. E., Ozgun, H., \& Dereli, R. K., et al. (2012). A review on dynamic membrane filtration: materials, applications and future perspectives. Bioresource Technology, 122, 196-206.

[8] Ersahin, M. E., \& Ozgun, H., Tao Y, et al. (2014). Applicability of dynamic membrane technology in anaerobic membrane bioreactors. Water Research, 48, 420-429.

[9] Hou, L., Chen, M. D., Li, D. H., \& Zhou, R. J. (2008). Influencing factors of simultaneous nitrogen and phosphorus removal in novel integrated bioreactor. China Water Waste, 24(3), 21-25.

[10] Karthikeyan, O. P., \& Visvanathan, C. (2012). Effect of C/N ratio and ammonia-N accumulation in a pilot-scale thermophilic dry anaerobic digester. Bioresource Technology, 113, 294-302.

[11] Schwede, S., Rehman, Z. U., \& Gerber, M., et al. (2013). Effects of thermal pretreatment on anaerobic digestion of Nannochloropsis salina biomass. Bioresource Technology, 143, 505-511.

[12] Wang, H. Y., Ma, F., Su, J. F., Zhuo, W., Zhang, X. X., \& Zhang, J. (2007). Influence of carbon source and C /N ratio on nitrogen removal of aerobic denitrifier. Acta Scientiae Circum Stantiae, 27(6), 968-972.

[13] Zhao, C. H., Peng, Y. Z., Wang, S. Y., \& Tang, X. G. (2008). Effects of influent C/N ratio on performance of unifed SBR process. Environment Science, 29(5), 1210-1215.

[14] Aileen, N. L. N., \& Albert, S. K. (2007). A mini-review of modeling studies on membrane bioreactor (MBR) treatment for municipal wastewaters. Desalination, 212, 261-281.

[15] Pimentel, G. A., Wouwer, A, V., \& Harmand, J., et al. (2015).Design, analysis and validation of a simple dynamic model of a submerged membrane bioreactor. Water Research, 70, 97-108.

[16] Sperandio, M., \& Espinosa, M. C. (2008). Modelling an aerobic submerged membrane bioreactor with ASM models on a large range of sludge retention time. Desalination, 231, 82-90.

[17] Liu, R., Huang, X., Liu, R. P., \& Qian, Y. (2001). A comparison between a submerged membrane bioreactor and a conventional activated sludge process. Environment Science, 22(3), 20-24.

[18] Chinese NEPA. (2002). Water and Wastewater Monitoring Methods, 4rded. China, Beijing.

[19] Henze, M., Grady, C. P. L. J., Gujer, W., Marais, G. V. R., \& Matsuo, T. (1987). Activated Sludge Model No. 1 in IAWPRC Scientific and Technical Report No. 1. IAWPRC. London.

[20] Puigagut, J., Salvado, H., \& Garcia, J. (2005). Short-term harmful effects of ammonia nitrogen on activated sludge microfauna. Water Research, 39, 4397-4404.

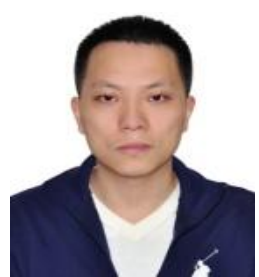

Ji-Zhi Lin was born on September 18, 1976 and studied in Southeast University (Nanjing, China) from1995 to 2002, majoring in biological sciences and medical engineering. After got the double bachelor's degree, Ji-Zhi Lin studied in Hua Qiao University (Xiamen, China) (2009-2011) and major in public administration and obtained a master's degree at 2011.

He is now a full working at Huaqiao University (Xiamen, China) and focusing on 
scientific research management and biological engineering. He has published many papers in the field of research, such as: Lin, J. Z., Qiang, W., Algorithm Design for Getting Faultage Image of Three Dimensional Volume Data (2006), Journal of Huaqiao University(Natural Science), 27, 4, 445-446.

Qian Zhang was born on October 26, 1986 and studied in Shanxi University (Taiyuan, China) in 2004-2008, majoring in environmental sciences. After got the bachelor's degree, Qian Zhang studied in Xiamen University (Xiamen, China) (2008-2011) and major in environmental engineering. Then she went on with her studies at National Taiwan University (Taipei, China) and obtained a doctorate at 2015.

She is now a postdoctor working at Huaqiao University (Xiamen, China) and focusing on advanced oxidation of water pollutions. Her work in this area ranged from catalysts preparation to the mechanism and kinetics evaluation of organics degradation. She has published many papers in the field of research, such as: Zhang, Q., Lin, C. F., Chen, B. Y., Tong, O. *, Chang, T. *, Deciphering visible light photoreductive conversion of $\mathrm{CO}_{2}$ to formic acid and methanol using waste prepared material (2015). Environmental Science \& Technology, 49, 2405-2417.

Jun-Ming Hong was born on October 4, 1974 and studied in Fuzhou University (Fuzhou, China) from 1992 to 1996, majoring in chemical engineering. After got the master's degree, Jun-Ming Hong studied in Xiamen University (Xiamen, China) (2002-2005)and major in environmental and obtained a doctorate at 2005.

He is now a full professor working at Huaqiao University (Xiamen, China) and focusing on wasterwater treatment. He has published many papers in the field of research, such as below: Hong, J. M., Jiang, J. S., Chang, C. T., Chen, B. Y., Comparative isocline analysis upon microbial decolorization in immobilized cell bioreactor using biocarriers(2013), Bioresource Technology, 145,313-320. 